\title{
The Media for Democracy Monitor applied to five countries: A selection of indicators and their measurement
}

\author{
LEEN D'HAENENS (the Netherlands), FRANK MARCINKOWSKI \\ and ANDRÉ DONK (Germany), TANJA MANIGLIO \\ and JOSEF TRAPPEL (Switzerland), JOAQUIM FIDALGO (Portugal), \\ AUKSĖ BALČYTIENĖ and EGLĖ NAPRYTĖ (Lithuania) \\ E-mails: leen.dhaenens@soc.kuleuven.be; frank.marcinkowski@uni-muenster.de; \\ adonk@uni-muenster.de; t.maniglio@ ipmz.uzh.ch; j.trappel@ipmz.uzh.ch; \\ jfidalgo@ics.uminho.pt; a.balcytiene@pmdi.vdu.lt; e.napryte@vks.vdu.lt.
}

\section{Introduction}

For the present inquiry of the performance of the news media as watchdogs of democracy in five countries (the Netherlands, Germany, Switzerland, Portugal, Lithuania), the bulk of the data was collected via desk research. Additionally, the researchers sought to fill any remaining gaps with complementary information gathered from interviews with media professionals, from a variety of publications such as official government documents, scholarly articles, and websites of the media institutions investigated in the study. Overall, the year of reference for the evidence collected was 2006. Furthermore, in the spring of 2008, expert interviews were conducted with key people whose inside knowledge has helped the researchers to evaluate and comment on a number of indicators.

The picture that results from the following country-specific section is far from complete, as only a small selection of indicators (three indicators for each of the five respective countries) is discussed in detail.

Within the principle of freedom, the F3 freedom indicator 'internal rules for newsroom democracy' looks into the autonomy of the individual members of the editorial staff. There can be no objective reporting of the news if the newsroom's freedom is restrained. The F3 indicator applied to the media situation in the five countries studied here seeks to ascertain whether any formal rules have been established within the editorial team. An example of such a rule might be a regular procedure for appointing the editor-in-chief: Is a democratic arrangement in place that takes the opinion of all the reporters on the staff into account? Furthermore, it is relevant to investigate whether the procedure, if any, is correctly followed. 
Referring to the control dimension, while the media may function as a societal watchdog, they are not at liberty to write or say just anything nor are they infallible to mistakes when carrying out their tasks. The C2 control indicator 'the watchdog and the media's mission statement' is designed to examine the tools the different media have to adequately perform their function as watchdog. Not only do the media need to be willing to perform this function, but they also need to be able to perform it. To do so, it is crucial that they have the appropriate means with respect to time and budgets. The excerpts of the country reports illustrate the state of affairs in the five countries under scrutiny.

The inventory also looks into the principle of equality as a pillar of democracy and the way this is followed up by the media under investigation. Indicators referring to this principle deal with concentration of ownership. Clearly, should all media be controlled by one single owner, the likelihood of portraying diverse content and a broad range of opinions is minimal. The Swiss example illustrates how the E1 equality indicator 'media ownership concentration at the regional level' assesses trends toward (quasi)-monopolies in relation to the size of the region.

Authors of the full country reports are Leen d'Haenens (the Netherlands), Frank Marcinkowski and André Donk (Germany), Tanja Maniglio and Josef Trappel (Switzerland), Joaquim Fidalgo (Portugal), and Aukse Balčytiené and Eglé Napryté (Lithuania).

\section{The Netherlands}

\section{Leen d'Haenens}

In the Netherlands, the following news media sample has been analyzed:

Print media. De Telegraaf (largest nation-wide newspaper), NRC Handelsblad (evening paper, one of the top Dutch newspapers in terms of quality), Het Parool (regional paper with a nation-wide readership), Elsevier (largest news magazine), De Gelderlander (regional daily), Meppeler Courant (largest informative paper of the province of Drenthe and the surrounding area), De Pers (free paper nationally available in railway stations).

Television and radio. NOS - TV news and Radio 1 (provider of news and sports for the public broadcasting system), RTL (commercial broadcaster, produces a number of news programs).

Online media. NOS Online (public broadcaster's website; presents an up-to-date overview of both domestic and foreign news as well as sports coverage). 
Indicator F3: Internal rules for newsroom democracy

Netherlands: 3 points

Most editorial teams in the Netherlands employ formal procedures for appointing an editor-in-chief, as indicated by the procedures of the editorial by-laws. In the case of De Gelderlander, for instance, the procedure is as follows: The editorial staff as well as the management can nominate a candidate for chief editor. Both parties also have the right to veto a candidate nominated by the other party. Ultimately, the two groups must reach a compromise before an editor-in-chief can be appointed. A number of newspapers and/or broadcasters even require the participation of the entire editorial board in the appointment of the editor-inchief, a step that is also included in the by-laws.

Most newspaper and broadcasting editorial staffs have by-laws with explicit rules defining appointment procedures. The likelihood of each successive election ending similarly is therefore great. The veto power of the management and the editorial staff implies that each party can block the appointment of a candidate not acceptable to them. Consequently, all interested parties will have to talk and reach an agreement and, in this sense, the procedure can be said to be truly democratic.

Indicator E1: Media ownership concentration at the regional level Netherlands: 1 point

Looking at overall turnover (regional and national), the four main players on the Dutch media market in 2006 are the Telegraaf Media Groep (784.5 million Euro), PCM Uitgevers (674.8 million Euro), Koninklijke Wegener (668.1 million Euro), and RTL Nederland (350.0 million Euro) (CvdM, 2007).

Newspapers. Concentration of newspaper ownership is greater at the regional than at the national level. The main reason is that many regional dailies are exclusively distributed in one single province (CvdM, 2007: 42). The figures for 2007 reveal that only three large publishers control the market of dailies nearly all provinces of the country, namely, Telegraaf Media Groep, Koninklijke Wegener, and NDC. The Telegraaf Media Groep is dominant in North Holland, with $60 \%$ of the market of dailies in that province. Wegener has a share of more than $50 \%$ in four provinces. $N D C$ has a share of some $60 \%$ in the provinces of Groningen, Friesland, and Drenthe (CvdM, 2007: 40). The province where concentration is most marked is Limburg, where Mecom currently controls nearly $80 \%$ of the market (Bedrijfsfonds voor de Pers, 2008). In recent years concentration in the market of regional dailies has increased. 
Television. In the market of regional television, ownership concentration is less striking than in regional dailies. In the provinces of Groningen and Friesland, regional channels had 3.8\% and 3.3\%, respectively, in 2007 (CvdM, 2008), and these are also the highest market shares of regional television channels.

Radio. The number of regional radio stations is larger than that of regional television channels. This particular market is therefore larger and commands more listeners than the television market. Here too we find that the market shares of the regional radio stations were largest in the provinces of Groningen and Friesland in 2007 (CvdM, 2007: 52).

It is in the market of regional dailies in particular that we find the highest degree of concentration. This suggests that 'equality' is less evident in the printed media at the regional level. Where only one single daily is available in a province, the likelihood of a diverse spectrum of opinions shrinks dramatically.

\section{Indicator C2: The watchdog and the media's mission statement} Netherlands: 3 points

Print media. It is up to each newspaper or magazine to determine the extent to which they will let their watchdog function play a role in the content of their news coverage. The mission statement of some of the newspapers selected (notably De Telegraaf, NRC Handelsblad, and Elsevier) shows that they seek to fulfill this function as diligently as possible. Apart from providing information and entertainment, De Telegraaf also strives to keep a watchful eye on the Dutch authorities and actually considers its watchdog function to be as important as its other functions. The same can be said of NRC Handelsblad, as indicated by the following quotation on its website (own translation):

The idea of liberty which we champion is not compatible with a belief in any kind of dogma and does not unquestioningly accept any authority. This stance implies relentless vigilance and constant assessment. It also implies vigilance with respect to ourselves, and self-scrutiny as well, for man is a creature of habit and finds it hard to part with long-standing habits and patterns of thinking - nothing that is human is foreign to us.

NRC Handelsblad sets great store by the following two goals: self-regulation and the on-going to factually report the news (NRC Handelsblad, 2007). Finally, Elsevier also actively endorses the watchdog function and considers information, verification, and entertainment among its principle activities (Elsevier, 2009). 
These three newspapers are in sharp contrast to the free daily newspaper De Pers. Entertainment and to-the-point news coverage appear to be the main concerns of the paper. De Pers focuses more on the entertainment aspects than its 'quality' rivals, e. g., NRC Handelsblad. From the portrayal that De Pers gives of itself, it can be concluded that the entertainment function is deemed to be more important than the watchdog function. The paper intends to focus on exclusive news reporting (on "what is deviant") rather than on investigative journalism and background information (De Pers, 2009).

Television, radio, and online media. In its mission statement, the public broadcaster NOS stresses the importance of providing information. The $N O S$ seeks to be the viewers' primary source of information and current news. NOS journalists are expected to produce balanced, reliable, and unbiased news stories. The mission statement does not as such emphasize the watchdog function of $N O S$ as a part of the public broadcasting system (NOS, 2007).

The same applies to the commercial operator $R T L$. Here too the focus is on providing news and information via various platforms and forms of distribution. The mission statement of $R T L$ repeatedly mentions interactive news coverage and the use of multimedia technology, and considers these two aspects to be synonymous with quality (RTL Nederland, 2007).

Referring to the media selected, the $\mathrm{C} 2$ indicator shows that the watchdog function in the Netherlands is held in high esteem, in practice as well as in theory. Popular newspapers, such as De Telegraaf, also employ journalists who regularly write extensive and penetrating articles and reports. Nevertheless, phenomena such as embedded journalism and the protection of whistle-blowers can be impediments to the work of the investigative journalist.

\section{References}

Bedrijfsfonds voor de Pers/Netherlands Press Fund (2008). Concentratie [Concentration], Retrieved January, 2008, from http://www.persmediamonitor.nl/cgi-bin/ display.cgi?path $=1 \_7$

Commissariaat voor de Media/Netherlands Media Authority (2008). Televisiemarkt [Television market], Retrieved February, 2008, from http://www.mediamonitor.nl/ content.jsp?objectid=CVDM:283

Commissariaat voor de Media/Netherlands Media Authority (2007). Mediaconcentratie in beeld: concentratie en pluriformiteit van de Nederlandse Media 2006 [Media concentration in the picture: Concentration and pluriformity of the Dutch media 2006]. Hilversum: CvdM.

De Pers (2009). Missie dagblad De Pers [Mission statement newspaper De Pers], Retrieved January, 2009, from http://www.depers.nl/dagblad/missie/

Elsevier (2009). Over Elsevier [About Elsevier], Retrieved January, 2009, from http:// www.elsevier.nl/web/Weekblad/Over-Elsevier.htm] 
NOS (2007). De NOS [The Netherlands broadcasting foundation], Retrieved December, 2007, from http://www.nos.nl/assets/service/nosnl_overdenos.html\#organisatie

NRC Handelsblad (2007). Onze beginselen [Our mission statement], Retrieved December, 2007, from http://www.nrc.n1/krant/article115102.ece/Onze_beginselen

RTL Nederland (2007). Over RTL Nederland [About RTL Netherlands], Retrieved December, 2007, from www.rtl.nl/service/rtlnederland/corporate

\section{Germany}

Frank Marcinkowski and André Donk

In Germany, the following news media sample has been analyzed:

Print media. Süddeutsche Zeitung (highest circulation quality newspaper), Bild (largest tabloid newspaper), Der Spiegel (most important news magazine)

Television and radio. Tagesschau (public service), RTL aktuell (private commercial), Deutschlandfunk (national, news-oriented public service radio)

Online media. Spiegel Online (one of the largest portals)

\section{Indicator F3: Internal rules for newsroom democracy}

Germany: 1 point

In Germany, journalists are not in full democratic control of the newsroom; there are some significant barriers to an effective and democratic organization of newsrooms. In most cases, there is a newsroom-council. Generally, this is referred to as a newsroom statute, established to ensure the internal freedom of the press (innere Pressefreiheit). Regarding the question of journalists' involvement in staff decisions, the answers vary. The management usually appoints editors-in-chief and, in most of the cases, journalists are not involved in the process. There are, however, two exceptions: (1) Since Spiegel employees own 50\% of the company shares, they also have direct influence on the selection of the editor-inchief. (2) Süddeutsche Zeitung has established a board of the leading editors that has a say in the choice of their editor-in-chief: This board can only impede the owners' choice by a quorum of two-thirds. The board of the leading editors consists of all members of the editorship, heads of departments, the leading editors, and the editing committee. The editorial staff elects the five members of this committee.

Similar findings emerged with regard to the engagement of other new staff. There are only two cases in which potential control and influence by a major number of employees or editors have been established. Five out of seven interview partners stated that there are no routines to in- 
volve journalists; generally, the decision lies with the editor-in-chief or the heads of department. Because of this prevailing hierarchical structure, only one point was awarded.

\section{Indicator E1: Media ownership concentration at the regional level Germany: 2 points}

In order to assess the regional media ownership concentration in Germany, two types of major communication areas need to be defined first. In the case of newspapers, local and regional news media refer to those media that are published in and report on one of the 439 German districts (Kreise und kreisfreie Städte). Regional news broadcasters operate at the level of the 16 German states. In some cases, these broadcasting stations cooperate with each other, such that there are only nine instead of 16 .

A closer look at ownership concentration in the regional newspaper market reveals a tendency toward monopolization. There are different investigations, all of which yield the same result: In most of the districts there is no competition between local or regional newspapers. Schütz counts 261 district towns with only one newspaper (2007: 561). In a secondary analysis on the basis of Schütz's statistics, we counted 217 monopoly-districts. Another study finds 250 districts without any competition between local newspapers (Möhring and Stürzebecher, 2008: 99). We conclude that monopolization in the field of regional or local press is high and is continuing to increase.

The situation is much better for radio. There are regional public broadcasting services and at least one commercial provider in all major German regions. Similar findings were revealed for the TV-market: Each of the nine regions is served by public broadcasting services. In public broadcasting, participation of social groups on the board is intended to guarantee internal pluralism. There are no commercial 24/7 services with exclusively regional contents, but some of the broadcasters provide regional and local time slots (Regionalfenster). Notable in this context are the regional programs produced by the two big commercial broadcasting companies, RTL-Group and ProSiebenSat1-Media AG. Their market share varies between 5 to $15 \%$, depending on the specific region. However, these programs only get 30 minutes of airtime per day, except Saturdays and Sundays, and are limited to the western part of Germany. Additionally, there are more than 260 commercial broadcasts with regional and local programming in each of the 16 states (ALM-Jahrbuch, 2006: 259 ff.). While there is some competition in regional radio markets between at least two regional competitors, their output is quite limited. 
Indicator C2: The watchdog and the media's mission statement Germany: 1 point

Most editors of the main German news media do not identify with the role of watchdog. Our findings corroborate the results of a previous survey that states that just $24 \%$ of German journalists see themselves as watchdogs (Weischenberg, Malik and Scholl, 2005: 279). When asked about how they would define their role in a democracy, the journalists did not use the term "watchdog" or refer to the corresponding profile of an unflinching watchman over, let alone a critic of, politics and politicians. They prefer to define their function as providers of impartial, fair, and balanced information. Some editors pointed out that the media do not have a legalized role as a controller of one of the state powers and that it would consequently be presumptuous to fulfill this function and play the part of a fourth power. Two of our interview partners also see the empowerment of citizens to partake in the political process as part of their function. In line with its tradition, only Spiegel confirms its active role as a permanent and adamant critic of society and politics, a self-definition that is illustrated in the founder Rudolf Augstein's statement that Spiegel is the "assault rifle of democracy." Corresponding to the fact that most journalists do not identify with the role of watchdog, there are no mission statements that would allow for this self-image.

Likewise, there are no mission statements that explicitly reference active investigative journalism. However, most interviewees emphasized that the importance of investigative journalism was so evidently included in their self-image/work routines that it did not require to be explicitly written out.

\section{References}

Weischenberg, S., Malik, M., and Scholl, A. (2006). Die Souffleure der Mediengesellschaft. Report über die Journalisten in Deutschland. Constance: UVK.

Arbeitsgemeinschaft der Landesmedienanstalten in Deutschland (2007). ALM Jahrbuch 2006. Berlin: Vistas Verlag.

Möhring, W., and Stürzebecher, D. (2008). Lokale Tagespresse: Publizistischer Wettbewerb stärkt Tageszeitungen. Media Perspektiven 2008(2), 91-101.

Schütz, W. J. (2007). Deutsche Tagespresse 2006. Media Perspektiven 2007(11), 560588.

Schütz, W. J. (2007a). Redaktionelle und verlegerische Struktur der deutschen Tagespresse. Media Perspektiven 2007(11), 589-598.

\section{Switzerland}

Tanja Maniglio and Josef Trappel

In Switzerland, the following media sample has been analyzed:

Print media. 20 Minuten (highest circulation free newspaper), Neue Zürcher Zeitung (leading quality newspaper) 
Television and radio. Schweizer Fernsehen DRS (public service television); Schweizer Radio DRS (public service radio); there are no nationwide private commercial television or radio services in Switzerland

Online media. Blick Online (one of the largest news portals)

Indicator F3: Internal rules for newsroom democracy

Switzerland: 0 points

Our interviewees alluded rather to restrictions than to democratic structures in the newsrooms. A newsroom council does not exist for any of the selected media outlets. For all cases, the nomination of the editorin-chief is exclusively in the hands of the management. In some instances, the acting editor-in-chief holds informal conversations concerning his/her successor with the heads of the editorial sections. However, this seems not influence the management's final decision. Four of five interviewees stated that there are no formal procedures (or company rules) to ensure journalists' participation in decision-making.

Indicator E1: Media ownership concentration at the regional level Switzerland: 1 point

The figures for 2006 reveal that a tendency toward monopolization exists. In nearly all Swiss regions the printed and audio-visual media are controlled by a single media company.

Calculations relative to the concentration of newspapers show that $22 \%$ of all 185 Swiss districts (Bezirke) represent real monopolies (the

Table 1. Swiss regions with dominant publishing houses (selection).

\begin{tabular}{|c|c|c|c|c|}
\hline Region & Publisher & Daily newspaper & Radio & $\mathrm{TV}$ \\
\hline Aargau/Midland & AZ Medien & $\begin{array}{l}\text { Mittelland Zeitung } \\
\text { Aargauer Zeitung }\end{array}$ & Radio Argovia & $\begin{array}{l}\text { Tele M1 } \\
\text { Tele Tell }\end{array}$ \\
\hline $\begin{array}{l}\text { Grisons/ } \\
\text { Southeastern } \\
\text { Switzerland }\end{array}$ & $\begin{array}{l}\text { Südostschweiz } \\
\text { Medien }\end{array}$ & Die Südostschweiz & $\begin{array}{l}\text { Radio Grischa } \\
\text { Radio Engadina }\end{array}$ & $\begin{array}{l}\text { Tele } \\
\text { Südostschweiz }\end{array}$ \\
\hline Basel & $\begin{array}{l}\text { Basler Zeitung } \\
\text { Medien }\end{array}$ & $\begin{array}{l}\text { Basler Zeitung } \\
\text { Baslerstab }\end{array}$ & Radio Basel 1 & - \\
\hline $\begin{array}{l}\text { Berne } \\
\text { (metropolitan area) }\end{array}$ & Espace Media & $\begin{array}{l}\text { Berner Zeitung } \\
\text { Der Bund }\end{array}$ & - & Tele Bärn \\
\hline
\end{tabular}

Source: Own research, based on Bonfadelli, Meier and Trappel (2006). 
respective leading newspaper covers $60 \%$ of all households). In 66 districts, newspapers hold a quasi-monopoly ( $45 \%$ of households have the same newspaper) ${ }^{1}$.

A further estimation of the regional degree of concentration can be carried out according to economy areas. For each economy area we can calculate the CR3, representing the market share of the three newspapers with the highest circulation (table 2). The selection of four economy areas in table 2 shows that size corresponds with concentration: The larger the size of the area, the more media concentration decreases. While the CR3 in the area of Zurich amounts to a total of $69.6 \%$, the area of Aargau reaches $94.5 \%$. Taking a closer look at the other two areas, a high regional newspaper concentration can be observed. Zurich is the only area that seems to be able to offer room for more than one publisher (previous analyses confirm this finding, e. g., Bonfadelli, Meier and Trappel, 2006, data for 2003/2004).

Newspapers concentration in selected regional economy areas

Table. 2 Economy area Aargau (197,094 households).

\begin{tabular}{lcc}
\hline Newspaper & Circulation & Market share in \% \\
\hline Mittelland Zeitung & 87,347 & 44.5 \\
Aargauer Zeitung & 87,069 & 44.4 \\
Tages Anzeiger & 11,143 & 5.8 \\
& & CR3: 94.7 \\
Neue Zürcher Zeitung & 6,286 & 3.2 \\
Neue Luzerner Zeitung & 2,235 & 1.2 \\
other newspapers & 2,307 & 1.3 \\
\hline Total & 196,387 & 100 \\
\hline
\end{tabular}

Table 3. Economy area Vaud (308,715 households).

\begin{tabular}{lcc}
\hline Newspaper & Circulation & Market share in \% \\
\hline 24 Heures & 77,312 & 62.5 \\
Le Matin & 24,821 & 20.0 \\
Le Temps & 12,697 & 10.0 \\
& & CR3: 92.5 \\
Le Courrier & 2,098 & 1.6 \\
Tribune de Genève & 1,864 & 1.5 \\
La Liberté & 1,768 & 1.4 \\
other newspapers & 3,196 & 2.5 \\
\hline Total & 123,756 & 100 \\
\hline
\end{tabular}


Table 4. Economy area Basel (295,360 households).

\begin{tabular}{lcc}
\hline Newspaper & Circulation & Market share in \% \\
\hline Basler Zeitung & 82,418 & 36.9 \\
20minuten & 67,764 & 30.3 \\
Mittelland Zeitung & 30,509 & 13.6 \\
& & CR3: 80.8 \\
Basellandschaftliche Zeitung & 23,476 & 10.5 \\
Neue Zürcher Zeitung & 8,127 & 3.6 \\
Aargauer Zeitung & 6,851 & 3.0 \\
Tages-Anzeiger & 2,601 & 1.1 \\
other newspapers & 2,049 & 1.0 \\
\hline Total & 223.795 & 100 \\
\hline
\end{tabular}

Table 5. Economy area Zurich (707,527 households).

\begin{tabular}{lcc}
\hline Newspaper & Circulation & Market share in \% \\
\hline 20minuten & 187,902 & 31.8 \\
Tages-Anzeiger & 153,391 & 26.0 \\
Neue Zürcher Zeitung & 69,421 & 11.8 \\
& & CR3: 69.6 \\
Zürcher Oberländer & 38,746 & 6.7 \\
Der Landbote & 35,367 & 6.0 \\
Zürichsee-Zeitung & 31,952 & 5.4 \\
Zürcher Unterländer & 23,947 & 4.1 \\
Mittelland Zeitung & 15,168 & 2.6 \\
Aargauer Zeitung & 15,101 & 2.6 \\
other newspapers & 19,432 & 3.5 \\
\hline Total & 590,427 & 100
\end{tabular}

The tables refer to daily newspapers published at least five times per week. Due to a lack of regional circulation data, the newspaper Blick is not included. Source: Own calculation, based on data from www.mediaperfomance.ch

\section{Indicator C2: The watchdog and the media's mission statement} Switzerland: 2 points

When asked about journalists' role in a democracy, the self-image of a watchdog was common to all the interviewees. While the role as a critically analytical intermediary between the public and the political elite is one that is taken seriously, some editors see their main task to be the provision of information. The need for independent information seems be a principle common to the selected news media. Only 20minuten stresses the importance of an active investigative journalism. Concerning the company's mission statements, only public radio and television di- 
rectly reference their function as a watchdog. Balanced coverage of political parties and electoral campaigns generally is ensured through informal agreements and internal guidelines and not necessarily in written format. All editors referred to this system as well-established. According to them, the system is able to function so well due to a culture of pluralism and a tradition of balanced coverage.

\section{Note}

1. These remarks are based on Trappel and Perrin (2006: 130). The authors in turn refer to the unpublished calculations by Roger Blum.

\section{References}

Bonfadelli, H., Meier, W. A., and Trappel, J. (Eds.). (2006). Medienkonzentration Schweiz: Formen, Folgen, Regulierung. Bern, Stuttgart, Vienna: Haupt.

Trappel, J. and Perrin, I. (2006). Medienkonzentration in der Schweiz. In H. Bonfadelli, W. A. Meier, and J. Trappel (Eds.), Medienkonzentration Schweiz: Formen, Folgen, Regulierung (pp. 109-138). Bern, Stuttgart, Vienna: Haupt.

\section{Portugal}

\section{Joaquim Fidalgo}

In Portugal, the following news media sample has been analyzed:

Print media. Correio da Manhã (largest daily newspaper), Público (most influential daily newspaper among decision and opinion-makers), Expresso (weekly, largest newspaper), Destak (daily free newspaper)

Television and radio. Radiotelevisão Portuguesa - RTP-1 (first public TV channel), Televisão Independente - TVI (the largest commercial TV channel), Rádio Renascença - $R R$ (leading radio company in terms of audience)

Online media. no relevant online media

Indicator F3: Internal rules for newsroom democracy Portugal: 2 points

Journalists' involvement in newsroom decisions has been formally and legally imposed since $25^{\text {th }}$ April 1974 (the revolution bringing democracy back to the country). The Portuguese Constitution itself states the right of journalists to elect newsroom councils. Subsequent laws (the Press Law, the Journalist Statute) elaborate further on this subject, adding, for example, the right of journalists to have a say in the editorial orientation of the news media, to vote for internal promotions, and to participate 


\section{Author's Copy}

in the development of the media's mission statement and in their internal codes of conduct ${ }^{1}$.

According to the law, all news media with a minimum of five journalists shall have a newsroom council. Most of them in fact have one - a known exception is the leading radio station Rádio Renascença, owned by the Catholic Church. Here, we were told by the editor-in-chief, the matter of instituting a newsroom council "was never raised." The journalists' opinions about the medium orientation and performance are expressed "on an informal basis, on the daily newsroom meetings," he added. They also do not vote when a new editor-in-chief is appointed.

This radio station, along with the free daily Destak (with a newsroom of only 9 journalists and also with no newsroom council), are the exceptions among the selected sample of leading media. All the others have active newsroom councils that are consulted when important decisions must be made and convene regularly for meetings presided over by the editor-in-chief. However, from our direct knowledge, and in spite of what is written in the law, we can attest that in various other media outlets the newsroom council is confined to formal consultations and has no real involvement in the editorial decisions. The role of the newsroom council was once much more important than it is currently.

The weekly Expresso has an internal Code of Conduct that was prepared by a member of the newsroom council. It was then sent on for approval by the editor-in-chief, the management and the publisher, as well as by an Editorial Council - a group of outstanding personalities from different areas (politics, culture, economy, science) who are periodically asked to comment on the strategy and performance of the newspaper.

The daily Público has a Style Book that is much more than an internal set of rules (it has been published, already in a $2^{\text {nd }}$ edition, and is sold in bookshops), as it goes far beyond the technical standards or procedures involved in producing a newspaper. Prepared with the active involvement of all the journalists, it explains and assumes several commitments of the newspaper toward its public, recalling the ethical principles and norms of the journalistic profession and developing them into more detail. It is an important instrument of accountability, because the readers often quote it when they criticize the newspaper or present their complaints to the newspaper's Ombudsman.

In conclusion, we can say that democratic control by journalists in the newsrooms does exist to a certain extent. It is favored by the legal dispositions on the subject and evidenced by the daily practice over the last 30 years in a democratic regime. 
Indicator E1: Media ownership concentration at the regional level Portugal: 2 points

It should be mentioned that "regions" are not a political entity in Portugal. Nevertheless, considering the geographical scope of the publications, there are many regional and local newspapers; however, they are generally very small and do not have a strong presence in the media industry.

There are some daily newspapers with a regional or local target with circulation rates usually between 5,000 to 10,000 copies a-day (Diário de Notícias da Madeira, a regional newspaper for the Portuguese Madeira Island, issues around 15,000 copies a-day). Some towns even have two daily small newspapers, as it is the case in Braga in the northern part of the country (Diário do Minho and Correio do Minho, 6,000 copies each).

Regarding the weekly press (more common at the regional level), there are hundreds of newspapers, usually small, rather traditional, not very professionalized and primarily sold by subscription. The largest weekly newspapers are $O$ Mirante (24,000 copies) and Jornal do Fundão (16,000 copies).

There are also many local radio stations. They too tend to be very small: most do not even have a newsroom or information services.

There are no regional TV stations, as they are not yet legally permitted (exceptions include some local Web TV stations and the two regional public television channels $-R T P$ in Madeira and Azores).

One of the biggest Portuguese media groups (Controlinvest) with an important presence in the national dailies also owns three regional newspapers (two dailies - in Madeira and Azores - and one weekly).

There are two regional 'groups' with some importance at this geographical level, both in the center of the country - Adriano Lucas and Sojormedia. The former one owns four small dailies (one exclusively online) and one weekly. The latter owns one small daily and six weeklies (as well as a regional radio station, an editorial company, and an advertising agency). However, they are not relevant for concentration, as regional and local weeklies are in the hundreds. Nevertheless, the latter group (Sojormedia) is expanding by trying to forge a nation-wide presence (two new weeklies have been announced, one for the North/Porto, and another for the South/Algarve). Furthermore, it recently announced it will launch a new national daily as well.

We conclude that the degree of concentration at this level is rather low and does not seem to affect pluralism and diversity of choice.

Indicator C2: The watchdog and the media's mission statement Portugal: 1 point

An analysis of the Editorial Statute of the different news media of this sample points to these main ideas: 
Radio Renascença. The Editorial Statute emphasizes the Catholic affiliation of the station and, therefore, adheres to the Human Rights and defends the dignity of all human beings. It also insists on the need for pluralistic, comprehensive, objective, and honest information with respect to journalistic professional standards and journalism ethics.

$R T P$. The particular social responsibility of a public television station is stressed in the company's mission statement, together with the need for "accurate and independent" information. The independence from any kind of power - "political, economical, religious or other" - is underlined, for the station is only committed to "its duty to inform citizens."

Público. The newspaper also purports total independence from any kind of political or economic powers and considers itself responsible solely to its readers. It stresses that "the existence of a well-informed and active public opinion" is "a fundamental condition for democracy and for the existence of an open, dynamic society."

Destak. In its very short statute, this free newspaper says it will be "independent from any political or economic power," and refutes all ideological influences. It also pledges to respect the ethical principles and rules of journalism.

Expresso. The issue of independence (including "from its advertisers") is mentioned here as well. It insists that news media should not serve any particular interests; they should always be "autonomous institutions through which the citizens, in conditions of liberty and pluralism, can look for all the information they need to make their choices."

Correio da Manhã. "Total independence" from all "powers and interests," whether economic, political, religious, or professional, is also underlined by this newspaper's Editorial Statute. Furthermore, it states it will be "firm" to condemn any "abuse of power" and promises to help to build an informed and critical public opinion, regarded as an "essential instrument of an adult democracy."

From this sample, we can conclude that the news media only indirectly refer to their watchdog mission or to their commitment to investigate and control the different powers present in the society. The common thread between these Portuguese news media is their general promise to remain independent.

\section{Notes}

1. The first version of the Press Law, issued in 1976, even stated that the vote of the newsroom council for the appointment of the editor-in-chief was decisive: No one could be appointed against that vote. However, later issues of the law turned that vote into a consulting one, which is sometimes respected and sometimes is not. (In 
the case of public TV and radio, the appointment of the editor-in-chief depends on the vote of the Media Regulatory Entity - ERC).

\section{Lithuania}

\section{Auksè Balčytienè and Eglè Naprytè}

In Lithuania, the following news media sample has been analyzed:

Print media. Lietuvos rytas (national daily), Kauno diena (regional daily), Vakaro žinios (tabloid daily), 15 minučiu (free daily)

Television and radio. TV3 (private commercial broadcaster); LTV (public service broadcaster), Žiniu radijas (commercial radio station), LRI (public service radio station)

Online media. Delfi.lt, Bernardinai.lt (online news portals)

\section{Indicator F3: Internal rules for newsroom democracy}

Lithuania: 1 point

Basic editorial standards are defined in the Law of Provision of Information to the Public. These standards are legally binding for all media (both offline and online). In most media organizations, however, there are no formal procedures on how to involve journalists in decisions on personnel or editor-in-chief choices. Most frequently, the chief editor is appointed by the owners or a director, even though journalists of $15 \mathrm{mi}$ nučiu were once asked to suggest a candidate. In the news media analyzed, the selection of new journalists is usually done by the chief editor or the head of the news department (15 minučiu, Vakaro žinios, TV3, radio and TV newsrooms of public service broadcaster). Once in a while, other employees are involved into this decision-making process; they are however frequently employees with higher positions in the newsroom (Kauno diena, Delfi.lt, Žiniu radijas). The entire newsroom staff is consulted only in the Internet portal Bernardinai.lt, although the final decision is ultimately made by the chief editor.

Institutionally, the law requires producers of public information programs to have their own internal codes of ethics, which "must set the journalist's rights, duties, responsibility, employments relations, as well as the journalist's protection against restriction of his rights." It pins down the journalists' duties, including the duty "to refuse an assignment by the producer, the disseminator of public information, their representative or a responsible person appointed by them, if this assignment compels [the journalist] to violate the laws or the Code of Ethics of Lithuanian Journalists and Publishers."

In most cases, the requirement for an internal code of ethics is implemented only formally, as there is no legally binding commitment to ensure editorial independence. 
Indicator E1: Media ownership concentration at the regional level Lithuania: 2 points

Despite the fact that media regulation in Lithuania is liberal and all kinds of ownership forms (cross-media, diagonal, foreign ownership) are possible, media concentration has not been an issue of great concern until recently. With general economic growth in the country and changing patterns of media use, the picture, however, has changed rapidly.

The audience share and reach of local and regional TV channels has slowly increased over recent years. In 2006, the market of regional and local broadcasting included one regional broadcaster and 27 local commercial TV stations. The country was served at the time by 57 cable operators and four Multichannel Multipoint Distributed Service (MMDS) operators. The number of regional local broadcasters and cable operators has remained stable. According to the media law, a regional broadcaster shows terrestrial programming to a territory inhabited by less than 60 percent of Lithuania's population. Local broadcasting is defined as programming aired by one radio or television station, regardless of its reach and penetration. Rules on licensing regional and local broadcasters are the same as for nationwide broadcasters. In its annual reports, the Radio and Television Commission of Lithuania (RTC) states that regional and local broadcasters are monitored on a regular basis. Sanctions against them were exceptionally rare: once in 2005 and three times in 2006. No comprehensive data on this monitoring are publicly available.

In general, regional concentration is fairly low; in most cases more than two competing news media outlets are available in each sector. Market share (CR3) in the regions of Lithuania cannot be calculated, as no relevant data is available.

\section{Indicator C2: The watchdog and the media's mission statement Lithuania: 1 point}

The representatives of the selected news media describe the watchdog role as one of the most important functions of media; priority is however placed on the mission of informing society and presenting the broadest scope of various opinions. In these answers, the locus of news is clearly pulling away from politics and seeking a more immediate connection to the everyday life of individuals. Journalists claim that it is important to report news that has tangible consequences for ordinary citizens. This kind of journalism takes a keen interest in public opinion (who reads and watched what). As a matter of fact, these respondent answers refer to the process of secularization, understood as decline of a political order 
based on collective political actors and identities (such as religion, political parties or trade unions) and their replacement by a more fragmented and individualized society. It may be observed that some representatives of the selected news media have a varied understanding of the watchdog function. For example, the chief editor of the daily Kauno diena and the head of the radio news department at the public service broadcaster associated it with the presentation of a concrete author's opinion toward certain occurrences. The chief editor of the daily Kauno diena expressed her opinion that the watchdog function is currently being transformed into the production of balanced and wide-ranging information. As she explained, this function in Kauno diena is fulfilled by the selection of certain topics (analyzing, for example, the work of national enterprises).

\section{Bionotes}

Leen d'Haenens is Associate Professor at the Centre for Media Culture and Communication Technology, Katholieke Universiteit Leuven, Belgium, and Department of Communication Studies, Radboud University Nijmegen, The Netherlands.

Frank Marcinkowski is Professor at the Institute of Communication Science (ifk), Westfälische Wilhelms-Universität, Bispinghof 9-14, 48143 Münster, Germany.

André Donk is Doctoral Candidate at the Institute of Communication Science (ifk), Westfälische Wilhelms-Universität, Bispinghof 9-14, 48143 Münster, Germany.

Tanja Maniglio is Research Assistant at the Institute of Mass Communication and Media Research, University of Zurich, Andreasstrasse 15, CH-8050 Zürich, Switzerland.

Josef Trappel is Visiting Professor at the University of Vienna, Austria and Lecturer at the Institute of Mass Communication and Media Research, University of Zurich, Andreasstrasse 15, CH-8050 Zürich, Switzerland.

Joaquim Fidalgo is Assistant Professor at the Instituto de Ciências Sociais, University of Minho, Campus de Gualtar, 4710 - 057 Braga, Portugal.

Aukse Balčytiene is Associate Professor at the Department of Public Communication, Vytautas Magnus University, Donelaičio 58, LT-44248 Kaunas, Lithuania.

Egle Napryte is Assistant at the Department of Public Communication, Vytautas Magnus University, Donelaičio 58, LT-44248 Kaunas, Lithuania. 